\title{
Assessment of Selected Serum Electrolyte and Associated Risk Factors in Diabetic Patients
}

This article was published in the following Dove Press journal:

Diabetes, Metabolic Syndrome and Obesity: Targets and Therapy

\author{
Shiferaw Bekele Woyesa \\ Waqtola Cheneke Gebisa (iD \\ Delebo Lefebo Anshebo \\ Jimma University, Institute of Health \\ Science, School of Medical Laboratory \\ Science, Jimma, Ethiopia
}

Purpose: The objective of this study was to assess selected serum electrolytes imbalance and associated factors in diabetic patients attending their follow up appointments in Jimma University Medical Center (JUMC) from February 1 to April 1, 2019.

Patients and methods: A cross sectional study design was used to assess the selected serum electrolytes in diabetic patients attending their follow up appointments at Jimma University Medical Center (JUMC) chronic illness clinic. A convenience sampling technique was used to include 279 diabetic patients in the study and an interviewer based questionnaire was used to include all necessary data from each diabetic patient. Five milliliters of blood were collected from each subject and processed and analyzed for blood glucose and serum electrolyte determination by ABX Pentra400 and Humalyte plus ${ }^{5}$ ion-selective electrode (ISE) system clinical chemistry analyzers. Pearson's correlation coefficient model and multivariate logistic regression were used respectively to assess the correlation and significant association between abnormal serum electrolytes and independent variables.

Results: A high prevalence of one or more serum electrolyte abnormalities was determined in diabetic patients. The overall prevalence was $42.0 \%(\mathrm{n}=116 / 276)$ in which hyponatremia was the highest followed by hypochloremia and hypercalcemia, $40.6 \%, 14.9 \%$ and $10.9 \%$ respectively. Age, type of medication, and high body mass index (BMI) had strong positive correlations with abnormal serum concentration levels of sodium $(\mathrm{r}=0.611, \mathrm{P}=0.731)$, potassium $(\mathrm{r}=0.752, \mathrm{P}=0.812)$ and chloride ( $\mathrm{r}=0.645, \mathrm{P}=0.459)$. Being employed (AOR: 3.933, 95\% C.I: 1.057-14.637, P value: 0.041 ), treated with mixed medications (AOR: 2.9, 95\% C.I: $1.292-6.441$, P value: 0.010 ) and being unable to control blood glucose level or being hyperglycemic (AOR: 3.2, 95\% C.I: 2.179-5.721, P value: 0.000) were statistically identified as risk factors for serum electrolyte abnormalities in diabetic patients.

Conclusion: The serum electrolyte concentration level was highly abnormal in diabetic patients. The prevalence of abnormal concentration was more common in diabetic patients with advanced age, and some variables had strong positive correlation with abnormal serum electrolyte level in diabetic patients.

Keywords: hyperkalemia, diabetic patients, hyponatremia, Jimma University

\section{Introduction}

Body fluid is an aqueous solution containing electrolytes and non-electrolytes, consisting of intracellular and extracellular compartments. ${ }^{1,2}$ Most metabolic activities primarily occur in intracellular fluid (ICF), due to this, substantial alteration in its ionic strength may occur with adverse effects on body function. Extracellular fluid (ECF) functions efficiently as a conduit and regulates intracellular volume and its ionic strength, because of this, it requires maintenance of optimal volume. Any alteration in extracellular osmolality is followed by an identical change in intracellular
Correspondence: Shiferaw Bekele Woyesa Tel +25147I I I 875

Email bekeleshiferaw@yahoo.com 
osmolality, which is accompanied by a reciprocal change in cell volume because an osmotic equilibrium exists between the cells and the extracellular fluid. ${ }^{1,3-6}$

Electrolytes are substances that become ions in solution and acquire the capacity to conduct electricity. ${ }^{7,8}$ Electrolytes are an essential component in numerous processes including body fluid volume and osmotic regulation $\left(\mathrm{Na}^{+}, \mathrm{K}^{+}\right.$and $\left.\mathrm{Cl}^{-}\right)$, myocardial rhythm and contractility, and neuromuscular excitability (e.g., $\mathrm{K}^{+}$) as well as acidbase balance (e.g., $\mathrm{K}^{+}, \mathrm{Cl}^{-}$). ${ }^{1,8}$ Sodium and chloride ions are the main electrolytes in the extracellular fluid whereas potassium; magnesium and phosphate are the main electrolytes in the intracellular fluid. Diffusion of cellular $\mathrm{K}^{+}$ out of cells and $\mathrm{Na}^{+}$into cells is caused by trans-membrane electrical gradients. Sodium-potassium ion $\left(\mathrm{Na}^{+}-\mathrm{K}^{+}\right)$ pump, which is stimulated by insulin and catecholamine hormones, reverses the movement of these electrolytes in order to maintain their extracellular and intracellular homeostasis. $^{1,4,8-10}$ Alterations of the levels of insulin and catecholamine affect the serum level electrolytes. ${ }^{1,5}$ Changes in the total amount of extracellular solute, osmotic dieresis, intake of water driven by thirst, and influences from associated conditions are the mechanisms that have been considered by which fluid and solute abnormalities occur in hyperglycemic patients. ${ }^{2,11-13}$

Hypo- and hyper-secretion of electrolyte disorder is the most common in hospitalized patients. Hypokalemia and hyperkalemia are when the serum concentration of potassium level is below $3.5 \mathrm{mmol} / \mathrm{L}$ and greater than $5.1 \mathrm{mmol} / \mathrm{L}$ respectively. Hyponatremia is when the sodium serum concentration is less than $135 \mathrm{mmol} / \mathrm{L}$ and hypernatremia is when its serum concentration is greater than $150 \mathrm{mmol} / \mathrm{L}$. Shift of electrolytes from the cells to the extracellular fluid or from extracellular fluid into the cells, increased intake and reduced renal excretion are the mechanisms by which their serum elevation may occur. ${ }^{1,2,8,11,14-19}$

Diabetes is a chronic condition that occurs when there are raised levels of glucose in the blood because the body cannot produce any or enough of the hormone insulin or use insulin effectively. ${ }^{20,21}$ Hyperglycemic hyperosmolar state is one of the acute complications of diabetes caused by inadequate fluid intake and absolute deficiency of insulin and it is characterized by hypotension, hyperosmolarity, and dehydration, and, with several weeks of polyuria, it may lead to electrolyte disorders in diabetic patients with different durations of hyperglycemia., 2,9,13,16,22-25 Hence, this study was aimed to assess selected serum electrolyte abnormalities and factors associated with the abnormality in diabetic patients.

\section{Materials and Methods Study Area and Data Collection Technique}

The study was conducted at Jimma University Medical center (JUMC) from February 1 to April 1, 2019. The study was conducted on both type 1 and type 2 diabetic patients attending their follow up at chronic illness clinic of JUMC. An institution-based cross-sectional study design was used to carry out the study and a convenience sampling technique and a singlepopulation proportion formula with $\mathrm{P}$ value $=0.29$ and $95 \%$ confidence interval were used to include a sample size of 279 diabetic patients. An interviewer administered questionnaire was used to collect socio-demographic, clinical, and substance use as well as anthropometric data. Diabetic patients with history of renal problems or disease and those on diuresis treatment during data collection period were excluded from the study. Blood pressure measurement was performed based on World Health Organization (WHO) guideline and diabetic patients with abnormal systolic and diastolic blood pressure measurements were considered hypertensive. Anthropometric measurement was carried out based on WHO guideline and body mass index (BMI) for each study subject was calculated by using simple calculation formula, $\mathrm{BMI}=$ weight over height square and the diabetic patients were classified as underweight $\left(<18.5 \mathrm{~kg} / \mathrm{m}^{2}\right)$, overweight $\left(25.0-29.9 \mathrm{~kg} / \mathrm{m}^{2}\right)$, obese $(\geq 30 \mathrm{~kg} /$ $\mathrm{m}^{2}$ ), or abnormal and normal weight $\left(18.5-24.9 \mathrm{~kg} / \mathrm{m}^{2}\right)$ based on WHO guideline category.

\section{Blood Collection and Analysis}

Five milliliters over-night fasting blood specimen was collected from each study subject and underwent necessary standardized procedures to separate the serum from the whole blood that is used for serum electrolyte and blood glucose determinations. A clinical chemistry analyzers, ABX Pentra400 and Humalyte plus ${ }^{5}$ ion-selective electrode (ISE) system were used for blood glucose and serum electrolyte determinations respectively. The international Federation of Clinical Chemistry (IFCC) recommended cut off values to categorize electrolyte values above and below normal range. Accordingly, the reference interval for sodium concentration level in the blood is 136-145 millimole per liter ( $\mathrm{mmol} / \mathrm{L}$ ) and those study subjects whose serum sodium concentration level below $135 \mathrm{mmol} / \mathrm{L}$ and greater than $146 \mathrm{mmol} / \mathrm{L}$ were considered to be hyponatremic and hypernatremic respectively. 
The reference interval for both chloride and potassium concentration levels in the blood are 98-107 mmol/L and 3.5$5.1 \mathrm{mmol} / \mathrm{L}$ respectively. Diabetic patients with serum chloride concentration level less than $98 \mathrm{mmol} / \mathrm{L}$ and above $107 \mathrm{mmol} / \mathrm{L}$ were considered to be hypochloremic and hyperchloremic respectively. Similarly, those study subjects with potassium serum concentration level below $3.5 \mathrm{mmol} / \mathrm{L}$ and above $5.1 \mathrm{mmol} / \mathrm{L}$ were considered to be hypokalemic and hyperkalemic respectively.

\section{Data Quality Management and Statistical Analysis}

All the data from the questionnaire were checked manually for completeness and clarity before any data analysis took place. After that the data were entered into Epidata version 4.1 and then exported to SPSS, IBM, USA version 23. Pearson's correlation was used to assess the strength of correlation between abnormal serum electrolytes and independent variables. Strengeth of correlation was considered very strong, strong, moderate, weak and very weak when the correlation coefficient value, $\mathrm{r}=0.8-1.0,0.6-0.79,0.4-$ $0.59,0.2-0.39$ and $0.0-0.19$ respectively based on the direction of the linear relationship between the dependent and independent variables. Bi-variate and multivariate logistic regression models were used to assess and identify independent predictor variables for serum electrolyte abnormality and those independent variables whose $\mathrm{P}$ values less than 0.25 in bivariate logistic model were shifted into multivariate logistic model. Finally, P value less than 0.05 was considered as a statistically significant association between independent variables and serum electrolyte abnormalities.

\section{Results}

The total response rate was $98.9 \%$ as three study subjects had been excluded before clinical sample analysis due to incomplete information. The age of study subjects ranged from 19-75 years with mean age of $50.9 \pm 13.7$. Majority of study subjects, $58.7 \%(n=162 / 276)$, were males and the rest were females. Three major serum electrolytes were assessed for each study subject and the overall prevalence of one or more abnormal serum electrolyte concentration level had been determined among 42.0\% ( $n=116 / 276)$ diabetic patients. Hyponatremia, serum sodium concentration level below $135 \mathrm{mmol} / \mathrm{L}$, was the leading abnormal serum electrolyte in diabetic patients followed by hypochloremia or low serum chloride concentration level
(40.6\% versus $14.9 \%$ ) respectively and only about $10.9 \%$ $(n=30 / 276)$ of diabetic patients were hyperkalemic or had serum potassium concentration level greater than $5.1 \mathrm{mmol} / \mathrm{L}$. Electrolyte abnormality was determined primarily among $22.8 \%(n=63 / 276)$ male diabetic patients and high prevalence, $15.6 \% \quad(n=43)$, was identified among diabetic patients with advanced age group or greater than 58 years. Moreover, the highest prevalence, $30.9 \%(n=85 / 276)$, was determined among married diabetic patients.

The correlation between serum electrolyte concentration level and independent variables was assessed by using Pearson's correlation coefficient model. Based on the assessment, serum electrolyte concentration level of sodium, chloride and potassium showed increment with marital status, duration of diabetes and diastolic hypertension. The age of diabetic patients had strong positive correlation with abnormal serum sodium concentration level $(r=0.611, \mathrm{P}=0.004)$ and weak positive correlation with abnormal serum chloride concentration level $(\mathrm{r}=0.33, \mathrm{P}=0.58)$ and very weak negative correlation with abnormal serum potassium concentration level $(r=-0.015, P=0.80)$. Type of medication used in diabetic patients had strong positive correlation with abnormal serum potassium concentration level $(\mathrm{r}=0.752, \mathrm{P}=0.001)$ whereas the abnormal serum concentration levels of sodium and chloride had very weak positive and negative correlation with type of medication used by diabetic patients $(r=0.05, \mathrm{P}=0.408$ versus $\mathrm{r}=-0.06, \mathrm{P}=0.321$ ) respectively. Abnormal serum concentration level of potassium had strong positive correlation with higher $\mathrm{BMI}(\mathrm{r}=0.645, \mathrm{P}=0.459)$, whereas sodium and potassium serum concentration levels had very weak correlation with abnormal BMI of diabetic patients (Table 1).

Bivariate and multivariate logistic regression was assessed to identify independent predicator variables that could have a statistically significant association with serum electrolyte abnormalities after the variables whose $\mathrm{P}$ values less than 0.25 in binary logistic regression had been shifted into multivariate logistic regression. Based on multivariate logistic regression statistical assessment, three variables were identified as having a statistically significant association with abnormal serum electrolytes. Employed diabetic patients were about 3.9 times more likely to develop abnormal serum electrolytes when compared to unemployed diabetic patients (AOR: 3.933, 95\% C.I: 1.057-14.637, P value: 0.041). Similarly, diabetic patients who were treated with both oral anti-hyperglycemic agent and insulin injection were about 2.9 times more likely to develop serum electrolyte abnormality than diabetic patients being treated with insulin alone to 
Table I Correlation Between Serum Electrolyte Parameter and Independent Variables

\begin{tabular}{|c|c|c|c|c|c|c|}
\hline \multirow[t]{2}{*}{ Predictor Variables } & \multicolumn{2}{|l|}{$\mathrm{Na}^{+}$} & \multicolumn{2}{|l|}{$\mathbf{K}^{+}$} & \multicolumn{2}{|l|}{$\mathrm{Cl}^{-}$} \\
\hline & $\mathbf{r}$ & $\mathbf{P}$ & $\mathbf{r}$ & $\mathbf{P}$ & $\mathbf{r}$ & $\mathbf{P}$ \\
\hline Sex & 0.039 & 0.517 & 0.33 & 0.580 & -0.015 & 0.800 \\
\hline Age & 0.611 & 0.004 & -0.45 & 0.454 & 0.072 & 0.231 \\
\hline Marital status & 0.074 & 0.218 & 0.22 & $0.7 I I$ & 0.025 & 0.674 \\
\hline Education & 0.005 & 0.929 & -0.092 & 0.128 & -0.004 & 0.943 \\
\hline Occupation & 0.103 & 0.089 & -0.004 & 0.943 & 0.039 & 0.520 \\
\hline Duration of diabetes & 0.097 & 0.107 & 0.057 & 0.342 & 0.039 & 0.520 \\
\hline Type of medication & 0.050 & 0.408 & 0.752 & 0.001 & -0.061 & 0.312 \\
\hline Hypertension & -0.076 & 0.206 & -090 & 0.134 & 0.023 & 0.699 \\
\hline BMI & 0.145 & 0.016 & -0.003 & 0.956 & 0.645 & 0.459 \\
\hline SBP & 0.106 & 0.078 & -0.002 & 0.976 & 0.174 & 0.004 \\
\hline DBP & 0.053 & 0.378 & 0.003 & 0.956 & 0.053 & 0.385 \\
\hline Alcohol drinking & -0.011 & 0.852 & 0.017 & 0.774 & 0.033 & 0.580 \\
\hline Cigarette smoking & 0.083 & 0.167 & -0.057 & 0.343 & 0.110 & 0.067 \\
\hline FBG & -0.225 & 0.000 & 0.110 & 0.068 & -0.208 & 0.001 \\
\hline
\end{tabular}

Notes: $r=$ Pearson's correlation coefficient, $p=p$ value for correlation, $\mathrm{Na}^{+}=$serum sodium, $\mathrm{K}^{+}=$serum potassium and $\mathrm{Cl}^{-}=$serum chloride.

Abbreviations: SBP, systolic blood pressure; DBP, diastolic blood pressure; FBS, fasting blood sugar.

monitor their blood glucose level (AOR: 2.9,95\% C.I: $1.292-$ 6.441, P value: 0.010). Moreover, diabetic patients who did not monitor their blood glucose level at normal or hyperglycemic diabetic patients were about 3.2 times more likely to develop abnormal serum electrolyte levels when compared to those whose fasting blood glucose level was not well monitored or hyperglycemic during study period (AOR:3.2, 95\% C.I: 2.179-5.721, P value: 0.000) (Table 2).

\section{Discussion}

Electrolytes play a vital role in maintaining homeostasis within the body by regulating fluid balance, oxygen delivery, acid-base balance, heart and neurological functions. However, the level of an electrolyte in the body can be too high or too low leading to an electrolyte imbalance. There was a high prevalence of one or more electrolyte abnormalities in diabetic patients in this study. Among serum electrolytes assessed, hyponatremia or low serum sodium concentration was the most prevalent abnormality in diabetic patients. ${ }^{2,13,16,21,24,26-31}$ The low serum concentration of sodium ion in diabetic patients may be due to osmotic diuresis induced hypovolemia. This means glucose is a substance with high osmotic activity, so its high concentration or hyperglycemia leads to increased serum osmolality that causes movement of water out of the cells and causes hypo-natremia by dilution. Hypokalemia or abnormally low blood potassium level was the second electrolyte imbalance assessed in diabetic patients. Other studies also identified abnormally low serum level of potassium in diabetic patients. ${ }^{2,3,16,26,28,32-35}$ The main reason for the abnormal level of potassium may be related to insulin treatment. When insulin is administered and glucose is taken up by the cells, potassium passes through the cell membrane along with glucose, decreasing the concentration of potassium both in blood and intracellular fluid. The other possible reason for hypokalemia is related to sodium-potassium pump which reverses the diffusion of cellular $\mathrm{K}^{+}$out of cells and $\mathrm{Na}^{+}$into cells caused by transmembrane electrical gradients. This sodium-potassium pump is stimulated by two hormones, insulin and catecholamine, through $\beta$-2-adrenergic receptors, and alterations in levels of these hormones can affect $\mathrm{K}^{+}$ transport and its serum levels. Diabetic hyperchloremia or high serum concentration level of chloride ion in diabetics was the third abnormal serum electrolyte assessed in this study. Similar findings were reported from different studies. $^{2,11,13,23,26}$

We also assessed the correlation between serum electrolyte abnormality and independent variables. Based on the finding some variables like cigarette smoking, abnormal BMI and age revealed positive correlation with hyponatremia and diabetic medication also revealed positive correlation with hypokalemia whereas cigarette smoking had positively correlated with hyperchloremia. Bivariate and multivariate logistic regression statistics were analyzed to assess the association between independent and dependent variables. Based on this assessment, three independent variables namely mixed medication (insulin plus 
Table 2 Bivariate and Multivariate Logistic Regression and Associated Risk Factors Among Diabetic Patients Assessed for Serum Electrolyte

\begin{tabular}{|c|c|c|c|c|c|c|c|}
\hline Variable & Category & COR & $95 \% \mathrm{Cl}$ & $P$ value & AOR & 95\% C.I. & $P$ value \\
\hline Sex & $\begin{array}{l}M \\
F\end{array}$ & $\begin{array}{l}0.732 \\
1\end{array}$ & $0.451-1.190$ & 0.208 & $\begin{array}{l}1.599 \\
1\end{array}$ & $0.958-2.787$ & 0.097 \\
\hline Age in years & $\begin{array}{l}19-28 \\
29-38 \\
39-48 \\
49-58 \\
\geq 58\end{array}$ & $\begin{array}{l}1 \\
1.079 \\
1.349 \\
0.911 \\
0.562\end{array}$ & $\begin{array}{l}0.383-3.042 \\
0.633-2.875 \\
0.453-1.830 \\
0.30 I-1.05 I\end{array}$ & $\begin{array}{l}0.885 \\
0.438 \\
0.793 \\
0.793\end{array}$ & $\begin{array}{l}1 \\
1.479 \\
1.349 \\
0.911 \\
0.562\end{array}$ & $\begin{array}{l}1.383-3.042 \\
0.633-2.875 \\
0.453-1.830 \\
0.301-1.051\end{array}$ & $\begin{array}{l}0.885 \\
0.438 \\
0.793 \\
0.793\end{array}$ \\
\hline Occupation & $\begin{array}{l}\text { Employed } \\
\text { Unemployed }\end{array}$ & $\begin{array}{l}0.305 \\
I\end{array}$ & $0.092-1.015$ & 0.053 & $\begin{array}{l}3.933 \\
1\end{array}$ & I.057-14.637 & 0.041 \\
\hline Type of DM & $\begin{array}{l}\text { Type } 2 \\
\text { Type } 1\end{array}$ & $\begin{array}{l}1.085 \\
\mathrm{I}\end{array}$ & $0.663-1.776$ & 0.746 & $\begin{array}{l}2.149 \\
1\end{array}$ & $0.947-4.875$ & 0.067 \\
\hline Diabetes duration & $\begin{array}{l}5-15 \text { years } \\
\leq 5 \text { years }\end{array}$ & $\begin{array}{l}1 \\
0.800\end{array}$ & $0.382-1.677$ & 0.555 & 0.800 & $0.382-1.677$ & 0.655 \\
\hline Medication type & $\begin{array}{l}\text { Mixed (oral and Insulin) } \\
\text { Insulin alone }\end{array}$ & $\begin{array}{l}0.626 \\
1\end{array}$ & $0.387-1.013$ & 0.08 & $\begin{array}{l}2.885 \\
1\end{array}$ & $|.292-6.44|$ & 0.010 \\
\hline Hypertension & $\begin{array}{l}\text { Yes } \\
\text { No }\end{array}$ & $\begin{array}{l}1.189 \\
1\end{array}$ & $0.736-1.922$ & 0.480 & $\begin{array}{l}1.21 \\
1\end{array}$ & $0.736-1.922$ & 0.490 \\
\hline BMI & $\begin{array}{l}\text { Abnormal } \\
\text { Normal }\end{array}$ & $\begin{array}{l}1.171 \\
1\end{array}$ & $0.725-|.89|$ & 0.519 & $\begin{array}{l}1.171 \\
1\end{array}$ & $0.725-|.89|$ & 0.519 \\
\hline Alcohol drinking & $\begin{array}{l}\text { Yes } \\
\text { No }\end{array}$ & $\begin{array}{l}0.617 \\
1\end{array}$ & $0.227-1.674$ & 0.343 & $\begin{array}{l}0.617 \\
1\end{array}$ & $0.227-1.674$ & 0.343 \\
\hline Cigarette smoking & $\begin{array}{l}\text { Yes } \\
\text { No }\end{array}$ & $\begin{array}{l}1.386 \\
1\end{array}$ & $0.192-9.985$ & 0.746 & $\begin{array}{l}1.386 \\
1\end{array}$ & $0.192-9.985$ & 0.746 \\
\hline FBS & $\begin{array}{l}\text { Hyperglycemic } \\
\text { Normoglycemic }\end{array}$ & $\begin{array}{l}3.03 \\
1\end{array}$ & $0.176-0.524$ & 0.000 & $\begin{array}{l}3.20 \\
1\end{array}$ & $2.179-5.721$ & 0.000 \\
\hline
\end{tabular}

Abbreviations: BMI, body mass index; FBS, fasting blood sugar.

oral anti-hyperglycemic), abnormal fasting blood glucose level, and being employed were identified as independent predicator variables for the abnormality of serum electrolyte levels. ${ }^{23,31}$

\section{Limitation}

It is difficult to identify the causes of abnormal serum electrolytes in diabetic patients due to the nature of study design which describes only what is happening at a present time. We also did not try to compare the serum electrolyte concentration levels among type 1 and type 2 diabetics.

\section{Conclusion}

The overall serum electrolyte concentration level in diabetic patients was highly abnormal and the prevalence of abnormality was highest in diabetic patients with advanced age. The degree of correlations between the abnormal serum electrolyte concentration level and independent variables had great variation in diabetic patients.

\section{Ethical Consideration}

Ethical clearance was obtained from ethical review board of College of Health Sciences and then given to Jimma University Medical Center (JUMC) director's office. Next, a permission letter to conduct the study was obtained from the JUMC director's office and provided to the head of chronic illness clinic of JUMC. At the chronic illness clinic, the aim of the study was clearly explained to each study participant and then, informed consent was obtained voluntarily from each study subject before any data collection. The study was conducted in accordance with the Declaration of Helsinki. 


\section{Acknowledgments}

We would like to thank the study participants for voluntarily participating in this research project, Jimma University Medical Center laboratory for allowing us to use clinical chemistry analyzers, and Jimma University for funding the research project.

\section{Disclosure}

The authors report no conflicts of interest in this work.

\section{References}

1. Mcpherson RA, Pincus MR. HENRY'S Clinical Diagnosis and Management by Laboratory Methods. New York: Elsevier; 2011.

2. Liamis G. Diabetes mellitus and electrolyte disorders. World J Clin Cases. 2014;2(10):488. doi:10.12998/wjcc.v2.i10.488

3. Saito T, Ishikawa S, Higashiyama M. Inverse distri bution of serum sodium inpatients with diabetes uncontrolled and potassium mellitus in. Endocr J. 1999;46(1):75-80. doi:10.1507/endocrj.46.75

4. Bhave G, Neilson EG. Volume depletion versus dehydration: How understanding the difference can guide therapy. Am J kideny dis. 2011;58(2):302-309.

5. Ashraf R, Naikoo NA, Bashir H, et al. Research Article Electrolyte Imbalance in the Patients Admitted to the Emergency Department of the Tertiary Care Hospital of Smhs Hospital. Srinagar; 2018.

6. Blackmer BAB. Fluids and Electrolytes. In: PedSab Book 2. 2018:7-23. Available from: https://www.accp.com/docs/bookstore/pedsap/ ped2018b2_sample.pdf.

7. Houston MC, Harper KJ. Potassium, magnesium, and calcium: their role in both the cause and treatment of hypertension. $J$ Clin Hypertens (Greenwich). 2008;10(7 Suppl 2):3-11. doi:10.1111/ j.1751-7176.2008.08575.x

8. Bishop ML, Fody EP, Schoeff LE. Clinical Chemistry: Techniques, Principles Correlations. Philadelphia: Library of Congress; 2010.

9. Hasona NA, Elasbali A. Evaluation of Electrolytes Imbalance and Dyslipidemia in Diabetic Patients. Med.Sci. 2016;4(7):3-6.

10. Perez GO, Oster GR, Rogers AW . Acid-Base Disturbances in Gastrointestinal Disease. Digestive diseases and sciences. 1987;32:1033-1043.

11. Tzamaloukas AH, Ing TS, Siamopoulos KC, et al. Pathophysiology and management of fluid and electrolyte disturbances in patients on chronic dialysis with severe hyperglycemia. Semin Dial. 2008;21:431-439. doi:10.1111/j.1525-139X.2008.00464.x

12. Clinic M, Hospital Z, Clinical N, Hospital J. Acid-base and electrolyte managements in chronic kidney disease and endstage renal disease: case-based discussion. Blood Purif. 2018; 55905:179-186.

13. Anago EAA, Medehouenou TCM, Akpovi CD, Tchehouenou H. Electrolyte disturbances in diabetic patients in Cotonou, Benin. Int J Res Med Sci. 2016;4(12):5430-5435.

14. Liamis G, Rodenburg EM, Hofman A, Zietse R. Electrolyte disorders in community subjects: prevalence and risk factors. AJM. 2013;126 (3):256-263. doi:10.1016/j.amjmed.2012.06.037
15. Id KT, Nymo H, Louch WE, Ranhoff AH, Erik Ø. Electrolyte imbalances in an unselected population in an emergency department: a retrospective cohort study. PloS one. 2019;3:1-14.

16. Barkas F, Elisaf M. Diabetes Mellitus and Electrolyte Disorders. World J clin cases. 2014.

17. Perez V, Chang ET. Sodium-to-potassium ratio and blood pressure, hypertension, and related factors 1, 2. Adv Nutr. 2014;5(6):712-741.

18. WHO. Guideline: Potassium Intake for Adults and Children. Geneva: World Health Organization (WHO); 2012:2-52.

19. Vairo D, Bruzzese L, Marlinge M, et al. Towards addressing the body electrolyte environment via sweat analysis: pilocarpine iontophoresis supports assessment of plasma potassium concentration. Sci Rep. 2017:1-7. doi:10.1038/s41598-017-12211-y

20. Global report on diabetes.

21. Engwa GA, Nwalo FN, Attama TC, Abonyi MC. Influence of type 2 diabetes on serum electrolytes and renal function indices in patients. J Clin Diagn Res. 2018;12(6)13-16.

22. Larry Jemson J. Harrison 's Endocrinology. New York, Chigago: McGraw-Hill Companies; 2010.

23. Rana AK, Ray S. Dyselectrolytemia in hyperglycaemic crisis patients with uncontrolled non-insulin dependent diabetes mellitus. Int $J$ Med Res Health Sci. 2017;5(2):478. doi:10.18203/2320-6012.ijrms20170136

24. Billah MM, Rana SMM, Akter N, Hossain MS. Analysis of serum electrolyte and lipid profile in young Bangladeshi female with type II diabetes. Cogent Biol. 2018;4(1):1-10. doi:10.1080/23312025.2018. 1431474

25. Jha NK. Study of lipid profile \& electrolyte levels in diabetes. $J$ Med Health Res. 2017;3(9):146-148.

26. Wang S, Hou X, Liu Y, et al. Serum electrolyte levels in relation to macrovascular complications in Chinese patients with diabetes mellitus. Cardiovasc Diabetol. 2013;12(1):1-10. doi:10.1186/1475-2840-12-146

27. Nagai K, Ueda S, Tsuchida K, Doi T, Minakuchi J. Low serum sodium concentration is a prognostic factor related to current blood glucose level in stable hemodialysis patients: an observational study. Renal Replacement Therapy. 2017;3(1):1-9.

28. Article O. Prevalence of abnormal serum sodium and potassium concentration in paediatric new onset type 1 diabetes with ketoacidosis: a retrospective study from two Nigerian teaching hospitals. Sri Lanka J Diabetes Endocrinol Metab. 2018;8(1):32-39.

29. Icin T, Medic-stojanoska M. Multiple causes of hyponatremia: a case report. Medical Princ Pract. 2017;26(3):292-295.

30. Braun MM, Army M, Barstow WCH, et al. FEFF diagnosis and management of sodium disorders: hyponatremia and hypernatremia. Am Fam Physician. 2015;91(5).

31. Liamis G, Tsimihodimos V, Elisaf M. Hyponatremia in diabetes mellitus: clues to diagnosis and treatment. J Diabetes Res Clin Metab. 2015;6(6).

32. Murthy K, Harrington JT. Case report Profound hypokalemia in diabetic ketoacidosis. Endocr Pract. 2005;11(5):331-334. doi:10.4158/ EP.11.5.331

33. Ahmed SS, Nur F, Ullah R, Al Mamun A. Factors precipitating hypokalemia in diabetic patients: a cross sectional study. $J$ Enam Med Col. 2014;4:145-150. doi:10.3329/jemc.v4i3.20940

34. Sahay M, Sahy R. Hyponatraemia: A practical approach. Indian $J$ Endocrinol Metab. 2014;18(6):760-771.

35. Chatterjee R, Yeh HC, Edelman D, Brancati F. Potassium and risk of type 2 diabetes. Expert Rev Endocrinol Metab. 2011;6(5):665-672. doi:10.1586/eem.11.60 


\section{Publish your work in this journal}

Diabetes, Metabolic Syndrome and Obesity: Targets and Therapy is an international, peer-reviewed open-access journal committed to the rapid publication of the latest laboratory and clinical findings in the fields of diabetes, metabolic syndrome and obesity research. Origina research, review, case reports, hypothesis formation, expert opinion and commentaries are all considered for publication. The manuscript management system is completely online and includes a very quick and fair peer-review system, which is all easy to use. Visit http://www.dovepress.com/testimonials.php to read real quotes from published authors.

Submit your manuscript here: https://www.dovepress.com/diabetes-metabolic-syndrome-and-obesity-targets-and-therapy-journal 